\title{
Aplicação do Método Q para a Valoração da Paisagem de Morretes, Paraná, Brasil, como Subsídio ao Planejamento do Turismo
}

\author{
Application of Q Method for Valuation of Landscape Morretes, Paraná, Brazil, as \\ Allowance for Tourism Planning
}

\section{Aplicación de Método Q de Evaluación del Paisaje de Morretes, Paraná, Brazil, como Subsidio para el Planificación de Turismo}

\author{
Clarice Bastarz ${ }^{1}$ \\ Daniela Biondi ${ }^{2}$
}

\begin{abstract}
Resumo
Diante da crise ambiental, o turismo deve ser planejado para dirimir impactos nas paisagens, conservando seus aspectos estéticos, geográfico-ecológicos e culturais. Neste sentido, o objetivo desta pesquisa foi aplicar o "Método Q" para valorar e analisar as paisagens turísticas do município de Morretes para servir de subsídios às diretrizes de planejamento e gestão da paisagem para o turismo. Para isso, foram selecionadas e analisadas 9 paisagens representativas de Morretes, que foram colocadas em ordem de preferência, através do Método Q, por 207 respondentes (residentes, turistas e profissionais). Os resultados demonstraram que o Método $\mathrm{Q}$ foi eficiente e que as paisagens com maior percentagem de componentes naturais foram preferidas, embora estes componentes isolados não tenham sido suficientes para uma alta valoração. Isto indicou que o fator diversidade é determinante. $\mathrm{O}$ estudo também demonstrou que residentes, turistas e profissionais possuem preferências diferentes em relação à paisagem, demonstrando a importância do processo participativo de planejamento e gestão.
\end{abstract}

Palavras-chave: preferência da paisagem; componentes da paisagem; diversidade da paisagem; Floresta Atlântica, Método Q.

\section{Abstract}

Due to the environmental crisis, tourism should be planned to decrease impacts on landscapes, conserving their aesthetic, ecological, geographical and cultural aspects. In this sense, the goal of the research was to apply the "Q Method" to assess and analyze the

\footnotetext{
${ }^{1}$ Bacharel em Turismo, Mestre em Engenharia Florestal, Turismóloga da Secretaria da Agricultura e do Abastecimento do Paraná. Professora do Departamento de Turismo - Universidade Federal do Paraná. E-mail: clari_bastarz@yahoo.com.br

${ }^{2}$ Engenheira Florestal, Dra. Professora Associada III do Departamento de Ciências Florestais da Universidade federal do Paraná - UFPR, Bolsista de Produtividade em Pesquisa do CNPq. E-mail: dbiondi@ufpr.br.
} 
landscape of the tourist town of Morretes to provide inputs to the planning guidelines and landscape management for tourism. Thus, were selected and analyzed nine landscapes representing Morretes, which were placed in order of preference, by "Q Method", by 207 respondents (residents, tourists and professionals). The results showed that the " $Q$ Method" was effective and that landscapes with the highest percentage of natural components were preferred, although these separate components have not been sufficient for a high valuation. This indicated that the diversity factor is decisive. The study also showed that residents, tourists and professionals have different preferences in relation to the landscape.

Keywords: landscape preference; landscapce components; landscape diversity; Atlantic Forest; Q Method.

\section{Resumen}

Frente a la crisis ambiental, el turismo debe ser planificado para dirimir los impactos en el paisaje, conservando sus aspectos estéticos, geográfico-ecológicos y culturales. En esse sentido, el objetivo de esta investigación fue aplicar el método $Q$ para valorar y analizar los paisajes turísticos del municipio de Morretes para servir de subsidios a las directrizes de planificación y gestión del paisaje para el turismo.Para eso, fueron selecionados y analizados nueve paisajes representativos del municipio de Morretes que fueron colocados en orden de preferencia, a través del Método Q, por 207 entrevistados (residentes, turistas y profesionales). Los resultados demostraron que el Método $Q$ fue eficiente y que los paisajes con mayor porcentaje de componentes naturales fueron preferidos. A pesar de que estos componentes aislados no fueron suficientes para una alta valoración. Esto indicó que el factor diversidad es determinante. El estudio también demostró que residentes, turistas y profecionales poseen preferencias diferentes en relación al paisaje.

Palavras claves: preferencia de paisaje; componentes del paisaje; diversidad del paisaje; Foresta Atlantica; Método Q.

\section{Introdução}

A definição de turismo aceita do ponto de vista formal é dada pela Organização Mundial do Turismo (OMT, 2001, p.12): “o turismo compreende as atividades que realizam as pessoas durante suas viagens e estadas em lugares diferentes ao seu entorno habitual, por um período consecutivo inferior a um ano, com finalidade de lazer, negócios ou outras”. De acordo com Goeldner et al. (2002, p.23), qualquer tentativa de definir turismo e compreender sua abrangência deve levar em consideração os diferentes grupos sociais que participam deste fenômeno, como o turista; as empresas fornecedoras de bens e serviços; o governo da área ou 


\section{TURISMO EM ANÁLISE}

da comunidade anfitriã; e a própria comunidade anfitriã. Assim, segundo tais autores, o turismo pode ser definido como: "a soma de fenômenos e relações originados da interação de turistas, empresas, governos locais e comunidades anfitriãs, no processo de atrair e receber turistas e outros visitantes".

Inserindo a discussão do turismo na crise ambiental que se apresenta atualmente, faz-se urgente o planejamento das atividades humanas no espaço, pois, toda relação do homem com a natureza apresenta impactos, positivos ou negativos, imprimindo-lhe modificações e muitas vezes destruição. Dependendo do grau da degradação, as condições de vida da sociedade que ali vive são minadas. Portanto, é necessário impor limites, principalmente para os impactos negativos das diversas formas de utilização das paisagens, adequando-as aos processos de manutenção da funcionalidade e dinâmica da mesma. Pode-se afirmar que o resultado da interação entre homem e natureza é paisagem, pois de acordo com Canteras (1992, p.5), a paisagem é uma "realidade que o indivíduo constrói através da percepção de seu entorno, o qual ainda não é paisagem, enquanto o indivíduo não o tenha percebido".

Uma das formas de utilização da paisagem é o turismo, que, enquanto atividade humana transformadora, deve se adequar à sua capacidade. Este ajustamento contribui para a conservação das paisagens, bem como a manutenção do próprio turismo, já que este se apropria e depende delas. As características peculiares que constituem a identidade de um lugar atuam como recursos capazes de atrair turistas, a partir da sua percepção, seja in loco ou através de substitutos (gravuras, fotografias, slides, pintura e outros), conformam-se num "fator decisório de viagem", ou seja, influenciam na tomada de decisão das pessoas que querem viajar. Com a captação de turistas devido às características da paisagem, geram-se investimentos e benefícios advindos do turismo de ordem econômica, social, ambiental e principalmente humana. Desta forma, pode-se dizer que a valorização e o estudo desta no processo de planejamento do turismo são fundamentais para evitar a destruição e assegurar a sustentabilidade econômica, social e ambiental deste destino.

Através do Programa de Regionalização do Turismo - Uma Viagem de Inclusão foram identificados no Paraná 210 municípios turísticos arranjados em 10 regiões, sendo uma delas o litoral do Paraná. Esta região turística importante para o Estado conta com 7 municípios: 


\section{TURISMO EM ANÁLISE}

Antonina, Guaraqueçaba, Guaratuba, Matinhos, Morretes, Paranaguá e Pontal do Paraná. O município de Morretes apresenta-se como um dos destinos turísticos mais consolidados do Estado. Caracteriza-se principalmente pela vegetação e relevo, pois está situado no maior remanescente contínuo de Floresta Atlântica na Serra do Mar, embora possua patrimônio histórico-cultural significativo imprimido em sua paisagem. O turismo representa $55,8 \%$ do PIB de Morretes (Produto Interno Bruto). Isso significa que a atividade turística é muito importante para a economia e para a comunidade local (IBGE, 2009). Considerando que as paisagens do município significam grande parte da fonte de sustento da comunidade local, seria interessante entender como elas são utilizadas para/pelo turismo, como são valorizadas e percebidas por seus usuários (residentes e turistas), somando e contrastando com a percepção de profissionais que atuam no estudo do Turismo e Paisagem.

No entanto, os métodos para avaliação da preferência devem ser aprimorados na tentativa de diminuir tanto a subjetividade para a coleta de informações quanto a ampliação de atividades ligadas a paisagem, como o turismo. Neste sentido, o Método Q surge originado da psicologia como alternativa para a análise de preferências para o turismo. Sendo assim, o objetivo desta pesquisa foi aplicar o "Método Q" para valorar e analisar as paisagens turísticas de Morretes para servir de subsídios às diretrizes de planejamento e gestão para o turismo.

\section{2. Área de Estudo}

O município de Morretes possui área total de $685 \mathrm{~km}^{2}$, localiza-se a $86 \mathrm{~km}$ de Curitiba, capital paranaense, e a $38 \mathrm{~km}$ de Paranaguá, pólo econômico da região litorânea. A fronteira oriental de Morretes fica a cerca de $35 \mathrm{~km}$ do mar (figura 1). 


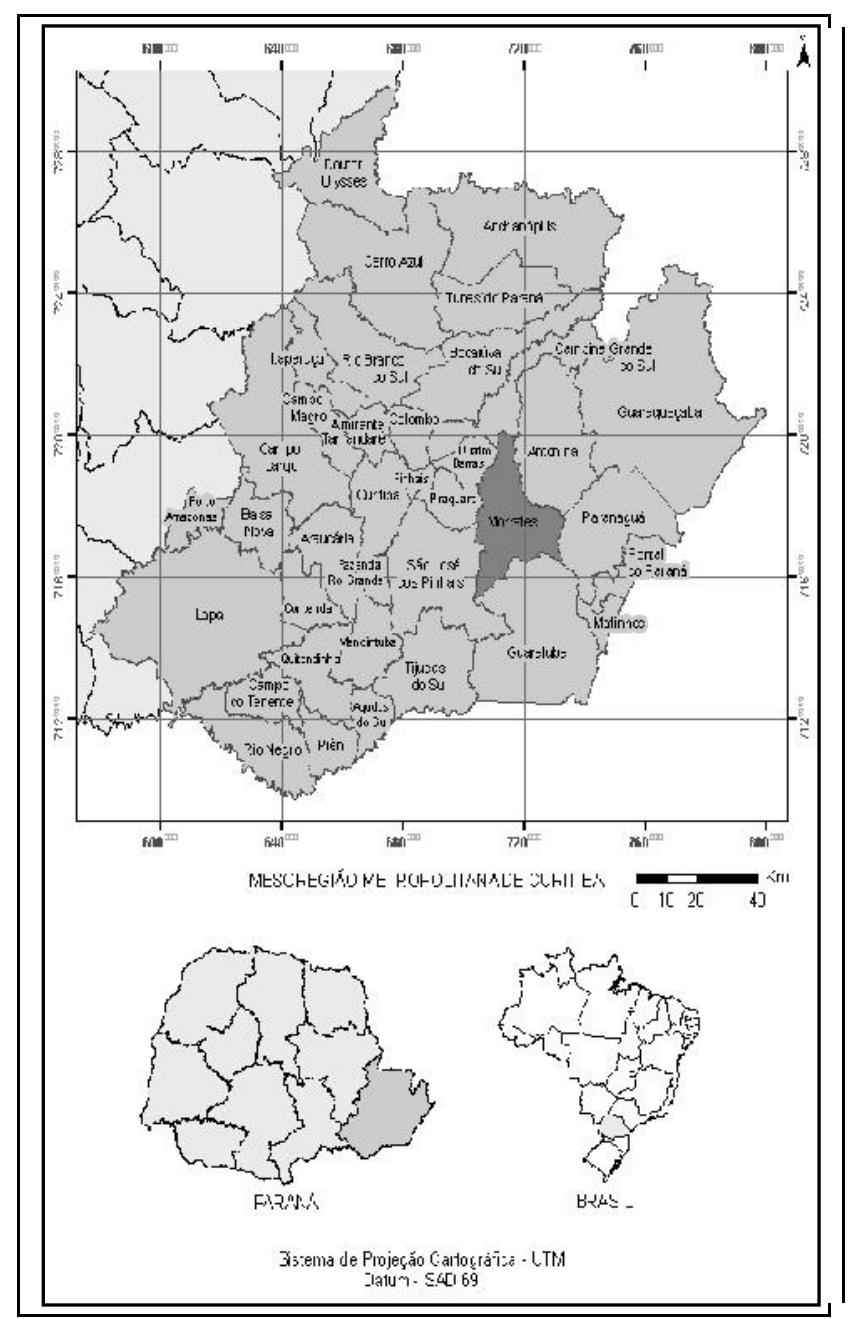

Figura 1 - Localização da área de estudo Fonte: GRISE, M.M. (2009).

O relevo, a vegetação, o clima e a hidrografia são os componentes que contribuem para a identidade da paisagem da área de estudo. Esta área é coberta por formações da Floresta Ombrófila Densa, porém apesar do grande potencial botânico do município devido à presença da Serra do Mar, a arborização de vias é bastante precária no perímetro urbano, caracterizando-se por poucas vias arborizadas e restando os miolos de quadras. Está localizada na região climática tipo Cfa, com clima subtropical úmido, mesotérmico, de verões quentes e geadas pouco frequentes, não apresentando estação seca. A média das temperaturas dos meses mais quentes é superior a $22^{\circ} \mathrm{C}$ e a dos mais frios é inferior a $18^{\circ} \mathrm{C}$. O município é 


\section{TURISMO EM ANÁLISE}

banhado pelos rios Nhundiaquara, Pinto e Marumbi e divide-se nas sub-bacias dos rios Mãe Catira, Sagrado, Marumbi, Pinto e Saquarema.

Em Morretes o setor secundário se destaca principalmente pelo comércio e serviços, dedicados principalmente à atividade turística, já que as indústrias não são significativas economicamente no município. Pode-se dizer que Morretes vive o ciclo econômico do Turismo. Esta atividade, além de ser responsável por 55,8\% do PIB municipal, se apropria e valoriza a História da região, a qual se torna um dos principais motivos para a atração de turistas e geração de renda para a cidade (PARANÁ CIDADE/SEDU, 2008).

Quanto aos aspectos turísticos de Morretes, o município possui um nível de atratividade natural e cultural que se destaca devido aos componentes de sua paisagem. Além dos recursos naturais, Morretes possui patrimônio cultural construído com a participação das diversas etnias que habitaram a região. Recebendo mais de 140 mil turistas ao ano (PARANÁ TURISMO/ SETU, 2006), Morretes conta com uma rede de equipamentos turísticos que oferecem serviços de hospedagem, alimentação, entretenimento e outros.

\section{Metodologia}

\subsection{O Método Q}

Originado do campo da Psicologia nos anos 30, no Método Q, o pesquisador procura analisar a relação entre as opiniões das categorias de indivíduos da população amostrada. O método Q é constituído por um grupo de afirmações, figuras ou fotografias (objetos) sobre um tópico (estímulo) pré-determinado pelos pesquisadores. A partir disso, os entrevistados são instruídos a classificarem esses objetos numa pirâmide em categorias que vão, por exemplo, de "mais gosto" (+3) para "menos gosto" (-3). A classificação resultante é, então, chamada de Q-Sort (FAIRWEATHER et al., 1998).

Para extrair as classificações, ou o Q-Sort, os respondentes são convidados a organizar as afirmações, figuras ou fotografias de uma forma significativa, de acordo com suas opiniões e impressões pessoais, de modo que cada um desses objetos ocupe um lugar na pirâmide de classificação (cada objeto deve possuir um lugar na pirâmide para que seja categorizado pelo 


\section{TURISMO EM ANÁLISE}

respondente, ou seja, se os pesquisadores decidirem avaliar 16 objetos, a pirâmide de classificação deverá possuir 16 lacunas). Normalmente, esses objetos são colocados pelos respondentes nas colunas da pirâmide de acordo com os valores atribuídos a estas colunas, que variam de positivo a negativo. Ao final do $Q$-Sort individual, os objetos recebem os valores correspondentes a sua coluna; e ao final do Q-Sort geral, de todos os respondentes, cada objeto tem seus valores atribuídos pelos respondentes somados, gerando o escore e a classificação final de cada objeto (BIGRAS e DESSEN, 2002).

O Método Q é diferente de outros métodos usados em estudos brasileiros que têm a percepção como foco de análise. No Brasil, técnicas de análise da percepção indireta através de objetos de arte, imprensa e literatura (BLEY, 1990; DEL RIO, 1999; LIMA, 1999; WANDERLEY e MENÊZES, 1999), entrevistas por questionários abertos ou fechados (PETROSILLO et al., 2007), elaboração de mapas mentais (BERTIN, 2003) e técnicas de análise de preferência visual (HABRON, 1998; MARENZI, 1996) são métodos bastante conhecidos e usados. No entanto, tais métodos, diferentemente do Q-Sort, que permite uma análise objetiva e sistemática dos resultados, abrem espaço para interpretações subjetivas por parte dos pesquisadores sobre os pontos de vista de turistas, moradores, empreendedores os quais são valiosos para a compreensão do funcionamento e da estrutura do Turismo. O Método Q pode, então, ajudar a analisar se existe concordância entre as opiniões dos respondentes, como e porque isso ocorre. A comparação de opiniões convergentes, complementares ou, às vezes, contraditórias pode ser extremamente valiosa para a pesquisa e para a tomada de decisões em relação ao Turismo (FAIRWEATHER et al., 1998).

Ao longo da pesquisa sobre este método, o mesmo mostrou-se pouco conhecido entre os pesquisadores que trabalham com o estudo da percepção de turistas, residentes e empreendedores do turismo. Apesar de serem poucos os estudos com a utilização do Q-Sort no Turismo, este método, de acordo com seus autores, se apresentou adequado e satisfatório no alcance dos objetivos e gerou uma riqueza de resultados fundamentados. Além disso, o método contribui para a qualidade em processos de tomada de decisões de planejamento ou para uma gestão sustentável das localidades turísticas. 


\section{TURISMO EM ANÁLISE}

\subsection{Procedimentos Metodológicos}

Para subsidiar a análise dos resultados extraídos pelo Método Q, foi realizada uma análise quantitativa das paisagens, baseada em Hardt (2000). Foi estabelecido que as fotografias (substitutos) selecionadas deveriam possuir o tamanho padrão de $10 \times 15 \mathrm{~cm}$, divididas em quadrículas de medida $0,4 \times 0,4 \mathrm{~cm}$, totalizando 900 quadrículas por fotografia. A quantificação dos componentes da paisagem foi realizada através da verificação de cada quadrícula das paisagens selecionadas, extraindo uma porcentagem de cada componente (natural e antrópico), sendo eles paisagísticos e turísticos. Com relação aos componentes paisagísticos, os elementos selecionados para a quantificação foram: a) naturais: relevo, céu, fauna, solo, vegetação e água; b) antrópicos: edificação, infraestrutura e elementos móveis. Quanto aos componentes turísticos, os elementos foram: a) naturais: céu, fauna, solo, vegetação e atrativos de sítios naturais; b) antrópicos: atrativos de manifestações históricoculturais, edificações diversas, equipamentos, infraestrutura e elementos móveis.

Foi estabelecido que as entrevistas deveriam ser realizadas em três categorias de sujeitos: residentes, turistas e profissionais das áreas de Turismo ou de Paisagem. Estas categorias foram estabelecidas com o objetivo de verificar se existiam padrões de preferências entre pessoas que possuem diferentes níveis de familiaridade com a paisagem ou com os conhecimentos teóricos sobre paisagem ou turismo. Os entrevistados foram selecionados de maneira aleatória e o número de amostras foi determinado pela predominância de uma mesma resposta, ou seja, os questionários foram tabulados ao final de cada dia de coleta e, havendo permanência do padrão de respostas, encerraram-se as coletas.

Em seguida à verificação da valoração das paisagens, através do Método Q, elaborou-se a análise das preferências utilizando os resultados das quantificações de seus componentes paisagísticos e turísticos. Foram feitas análises da preferência geral (todos os entrevistados sem distinção) e por categoria de entrevistado (residentes, turistas e profissionais).

\section{Resultados e Discussão}




\section{TURISMO EM ANÁLISE}

Para o processo de seleção dos substitutos (fotografias), foram fotografadas ao todo 437 cenas das regiões turísticas identificadas. As selecionadas foram as paisagens que melhor representaram estas regiões através dos componentes paisagísticos e turísticos que se apresentaram em cada uma delas. Foram escolhidas nove fotografias, levando em consideração também as semelhanças de perspectivas, planos de fundo e aspectos climáticos. A identificação de cada paisagem foi feita através de numeração atribuída de maneira aleatória. Dessa forma, as paisagens selecionadas foram:

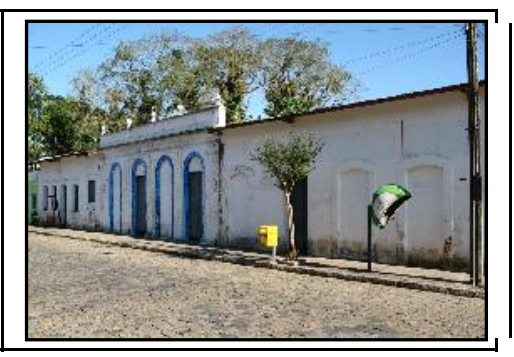

Paisagem 1

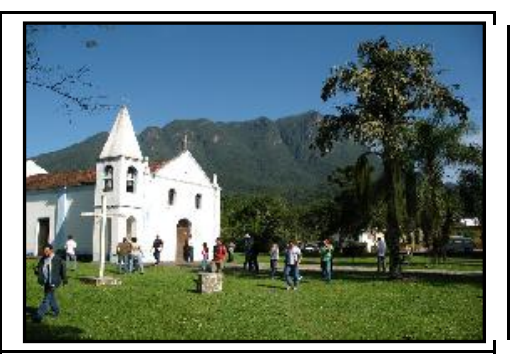

Paisagem 4

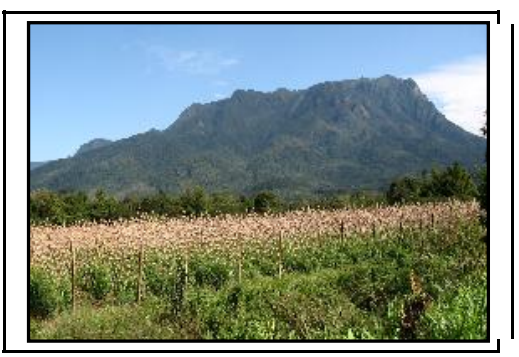

Paisagem 7

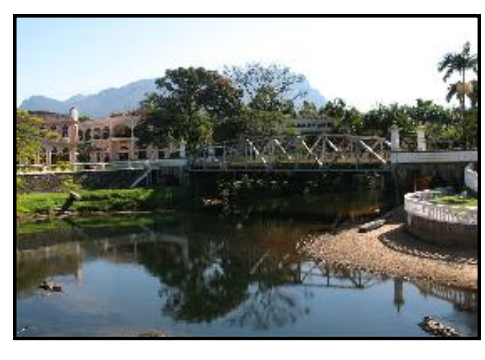

Paisagem 2

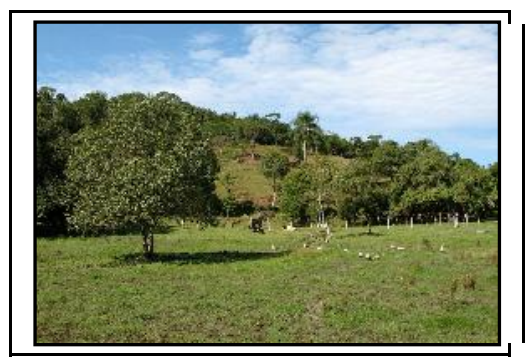

Paisagem 5

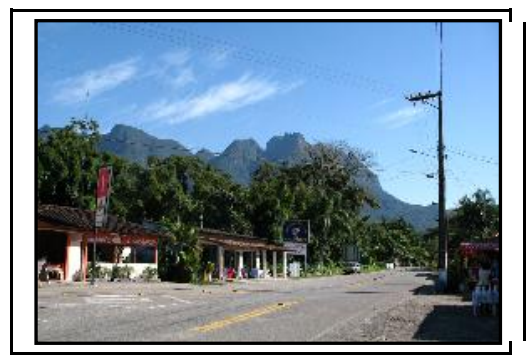

Paisagem 8

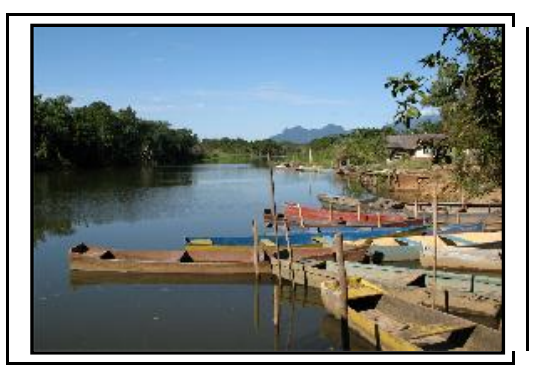

Paisagem 3

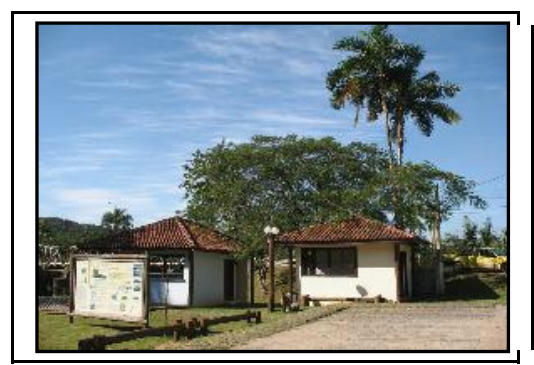

Paisagem 6

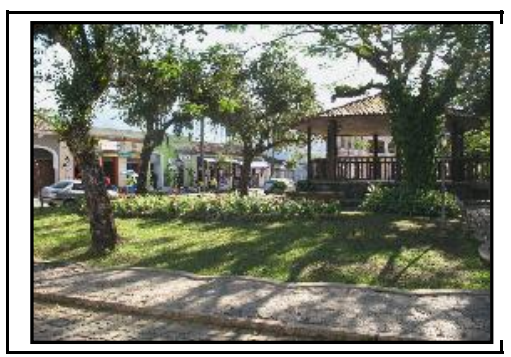

Paisagem 9

Figura 2 - Paisagens selecionadas

Fonte: as autoras (2009). 


\section{TURISMO EM ANÁLISE}

Foram coletados 207 questionários válidos, resultando em 130 turistas (63\%), 53 residentes $(26 \%)$ e 24 profissionais (11\%). Sendo 13 profissionais (professores universitários) da área de atuação Turismo, 7 de Paisagem e 4 de outras áreas, como geomorfologia, sociologia e urbanismo.

Com uma diferença de aproximadamente 4\%, o gênero dos entrevistados mostrou-se equilibrado. Foram 108 homens e 99 mulheres, com um total de 52\% e 48\% respectivamente.

Os entrevistados foram convidados a opinar sobre qual paisagem apresentada possuía mais elementos do turismo. Quase metade dos entrevistados, 47\%, afirmaram que a Paisagem 2 possuía mais elementos do turismo. Em segundo lugar, 31\%, a Paisagem 9 foi citada. Em terceiro lugar, apareceu a Paisagem 4, com 10\%. O restante das paisagens possuiu porcentagens menores do que $3 \%$.

Para a maioria dos entrevistados, o motivo de escolha das paisagens preferidas foi a presença de natureza na paisagem, $58 \%$. O segundo maior motivo foi o bom estado de conservação da paisagem, com 26\%; seguido pela presença de cultura, 9\%. Com 7\% aparecem outros motivos, que, pela descrição dos entrevistados seriam, em sua maioria a combinação de natureza e cultura, atribuindo o mesmo valor aos dois componentes da paisagem. Inexpressivamente aparece o mau estado de conservação, com $1 \%$.

Como resultado da pesquisa pode-se observar a figura 2, que apresenta os escores finais e a posição de cada paisagem na pirâmide. A paisagem 2 foi eleita como a preferida com escore final de 217 pontos, seguida da paisagem 9 com 96 pontos, paisagem 4 com 73 pontos, paisagem 7 com 64 pontos, paisagem 3 com 16 pontos, paisagem 8 com -52 pontos, paisagem 5 com -84 pontos, paisagem 6 com -149 pontos e paisagem 1 com -176 pontos.

A paisagem 2 foi a que teve maior valoração, resultando num escore de 217 pontos, conforme o Método Q. O valor máximo, +2, foi atribuído à paisagem 2 por $39 \%$ dos entrevistados. Possui a terceira maior porcentagem de componentes naturais $(82 \%)$ entre as paisagens selecionadas, perdendo para as paisagens $5(100 \%)$ e $7(83 \%)$. Isto contraria a tendência apontada por Zube e Pitt (1981), os quais afirmam que estudos de percepção demonstraram que as paisagens com recursos naturais são consideradas mais belas do que as com alguma interferência antrópica. 


\section{TURISMO EM ANÁLISE}

Com relação aos elementos dos componentes naturais, as percentagens de relevo plano (39\%) e acidentado (40\%) se apresentam equilibradas, embora a presença da montanha ao fundo contribua para a alta valoração da paisagem. De acordo com Canteras (1992), a presença de relevo acidentado possui uma importante relação com a qualidade da paisagem. $\mathrm{Na}$ opinião de Tuan (1980), as montanhas são um forte elemento estético na paisagem e para Pires (1996), quanto mais irregular o relevo maior valor visual é agregado à paisagem.

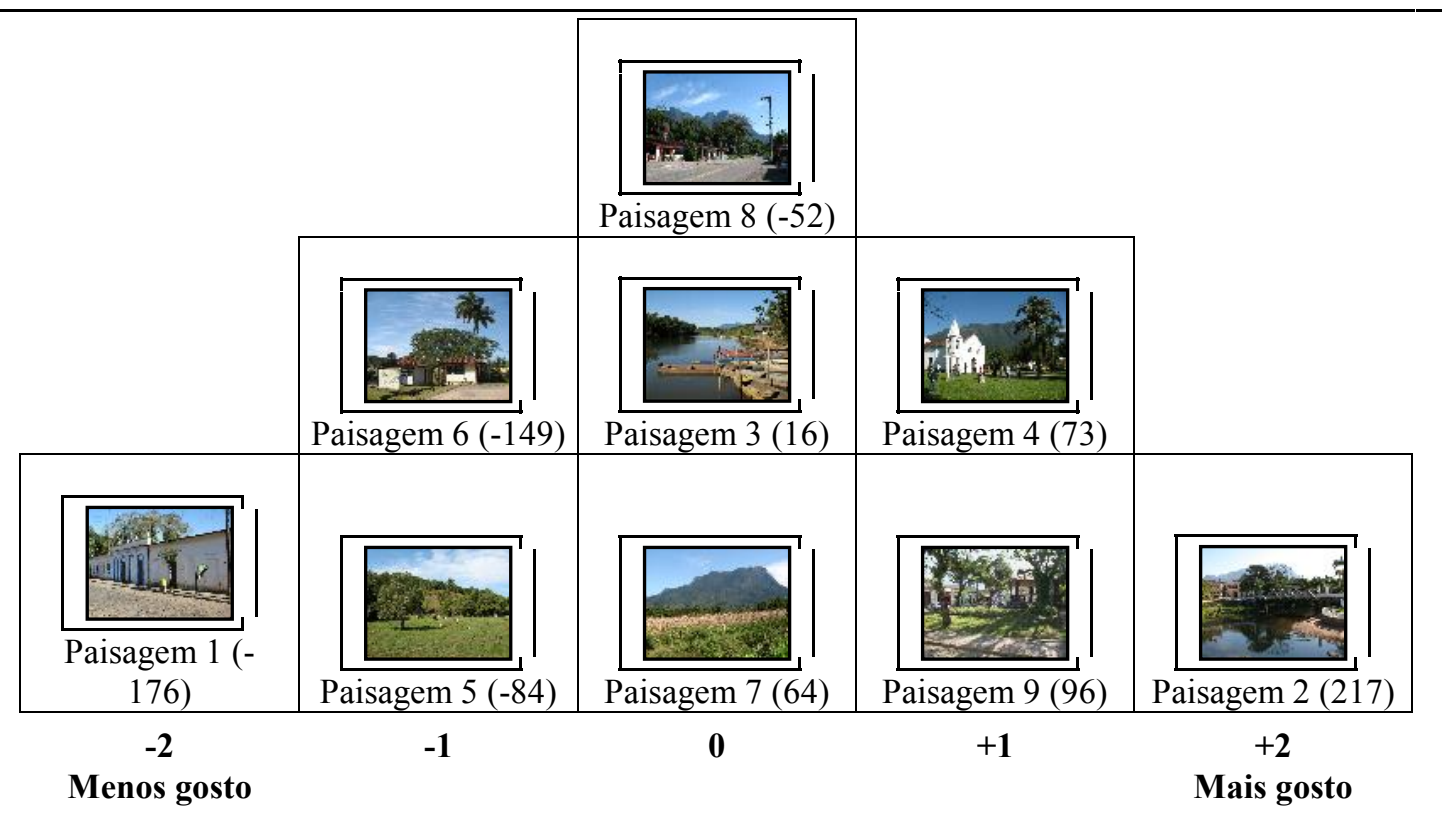

Figura 3 - Valoração das paisagens - q-sort geral

Fonte: as autoras (2009).

O elemento água aparece com bastante representatividade na paisagem 2 (33\%) em relação aos outros elementos. Este elemento é considerado por Tuan (1980) muito importante para o ser humano, não apenas no sentido biológico, mas pelo lado apreciativo. $\mathrm{O}$ autor afirma também que o encantamento do ser humano pela água deve ser algo herdado dos antepassados que procuravam se estabelecer próximos a rios, lagos e praias apropriados para a obtenção de alimentos, fixação, reprodução, aprendizado e desenvolvimento de habilidades manuais.

$\mathrm{Na}$ paisagem 2, o elemento vegetação, com 21\%, contribui para sua boa valoração. Concordando com este resultado, Hardt (2000) também verificou que a vegetação mostrou-se 


\section{TURISMO EM ANÁLISE}

um elemento de incremento da qualidade paisagística, quando estudou a qualidade da paisagem urbana de Curitiba (PR). Além disso, na paisagem 2, a vegetação também aparece ao redor do rio e, segundo Yázigi (2003), rios rodeados por vegetação são fonte intensa de atração das pessoas.

Quanto aos componentes antrópicos, que equivalem a $18 \%$ na paisagem 2 , o elemento edificação participa com $12 \%$ e infra-estrutura com $6 \%$. Entretanto, as edificações são predominantemente de arquitetura antiga (casario colonial) as quais não interferem negativamente na percepção dos entrevistados, pois estão em harmonia com a paisagem local. Neste sentido, Silva (2004) cita que o estilo arquitetônico colonial, pela sua singeleza, provoca um olhar romântico sobre o passado e a ideia de a paisagem estar esquecida no tempo provoca a imagem de um lugar primitivo, livre dos avanços da civilização industrial e tecnológica, da agitação das grandes cidades, cujo cenário é capaz de transportar as pessoas a outro tempo.

Por sua vez, a infra-estrutura também está em harmonia com a paisagem, sendo representada por uma ponte antiga, a qual pode ser considerada na classificação de Boullón (2002) como um marco na paisagem, pois atua como um artefato urbano destacado na paisagem que serve também como ponto de referência ao observador, capaz de aumentar a preferência pela paisagem.

Com relação aos componentes turísticos, o que chama a atenção para a paisagem 2 é o fato desta possuir a maior porcentagem de atrativos turísticos, que equivale a $48 \%$. O Rio Nhundiaquara e o Conjunto Marumbi representam os atrativos naturais, com $37 \%$ e os atrativos culturais (casario colonial) representam $11 \%$ da paisagem. A quantidade significativa do elemento atrativo na paisagem pode estar contribuindo para a preferência dos entrevistados. Boullón (2002) afirma que os atrativos são a matéria-prima para a atividade turística e que devem permanecer intactos, sofrendo intervenções apenas para manter sua integridade física. Pires (1996), neste sentido, também afirma que as culturas passadas e presentes são atrativos e contribuem para o turismo. As afirmações dos autores indicam a importância do elemento atrativo para a motivação da visita a Morretes (destino turístico) e indicam a relevância de sua presença para a preferência das paisagens. 
A paisagem 2 apresenta uma variedade de componentes paisagísticos e turísticos, razão pela qual é considerada diversa. Segundo Canteras (1992) e Pires (1996) a diversidade expressa uma variedade paisagística que existe num espaço e, então, uma paisagem variada possui mais valor que uma paisagem homogênea por possuir partes diferentes, com elementos visuais distintos e ausência de monotonia.

A paisagem 9 recebeu a segunda maior valoração, somou 96 pontos no escore final, sendo que $36 \%$ dos entrevistados atribuíram a ela o valor +1 . Em relação aos componentes paisagísticos, a paisagem 9 tem a segunda menor porcentagem de componentes naturais (64\%), perdendo apenas para a paisagem 1 (31\%), a qual recebeu menor valoração. A paisagem 9 recebeu alta valoração embora estudos apontem que a presença de recursos naturais na paisagem seja mais preferida pelas pessoas do que a presença de interferência humana (ZUBE e PITT, 1981; ZUBE et al., 1982). Isto pode ser um indício de que a paisagem 9 possui componentes antrópicos em harmonia com a paisagem natural, não gerando impactos visuais negativos.

Isolando o elemento relevo, a paisagem 9 é a que possui maior porcentagem de relevo plano (95\%). Este fato contradiz os resultados obtidos por Pires (1996), o qual verificou que as paisagens com ausência ou escassez de irregularidade no relevo foram classificadas como de qualidade visual baixa. Assim, acredita-se que a paisagem 9 apresenta outros elementos que neutralizam a ausência de relevo acidentado e justificam a sua alta valoração. Um desses elementos é a vegetação, que na paisagem 9 aparece com a segunda maior porcentagem (59\%), perdendo apenas para a paisagem 5 (69\%). Além disso, na paisagem 9, o elemento ocorre numa praça bem conservada e, de acordo com Silva (2004), a natureza controlada e domesticada oferece conforto necessário para que as pessoas consigam desfrutar das paisagens naturais.

Quanto aos componentes antrópicos (36\%), a paisagem 9 possui $14 \%$ de edificação, representada pelo casario colonial e pelo coreto. O elemento infra-estrutura presente na paisagem 9 aparece com 21\% (segunda maior porcentagem do elemento em relação às outras paisagens), representado pela rua e calçada em paralelepípedo. Estes elementos são predominantemente de estilo antigo e, assim como na paisagem 2, nota-se que quando estes 


\section{TURISMO EM ANÁLISE}

elementos se apresentam retratando a época colonial, não interferem negativamente na paisagem, pelo contrário, são reconhecidos como atração turística (Silva, 2004).

Em relação aos componentes turísticos, a paisagem 9 aparece com 34\%, constituídos por atrativo cultural $(7 \%)$, equipamento $(6 \%)$ e infra-estrutura $(21 \%)$. O atrativo cultural está representado pelo coreto, o qual pode ser considerado como um marco na paisagem e, de acordo com Boullón (2002), é algo que possui contraste na paisagem, se destacando dos outros elementos por sua singularidade. Por sua vez, a singularidade, conforme Pires (1996), se manifesta por ocorrências na paisagem que se tornam pontos de atração visual devido a seu caráter de exclusividade. Os equipamentos (lanchonete e lojas de artesanato), por sua vez, apesar da baixa porcentagem, se integram à paisagem 9 e contribuem para sua valoração, pois, segundo Boullón (2002), sua presença é que dá vida a qualquer local turístico.

A paisagem 9 também mostra uma praça, em primeiro plano, classificada por Boullón (2002) como logradouro. Segundo o autor, as praças são espaços públicos relativamente pequenos (em relação ao tamanho total da cidade), mas muito importantes para a formação da imagem turística da mesma. Destaca ainda que, se a praça possuir locais para sentar, as pessoas podem parar e admirar a paisagem do entorno com muito mais atenção, indicando um senso de funcionalidade à paisagem.

Com relação à diversidade, da mesma forma que a paisagem 2, a paisagem 9 apresenta uma combinação de componentes naturais e antrópicos variados, fato que, de acordo com Canteras (1992), contribui para a boa valoração da paisagem. No entanto, ao contrário da paisagem 2, a paisagem 9 possui um campo visual fechado e, conforme Boullón (2002), apresenta maior nível de detalhamento.

A paisagem 4 obteve a terceira maior valoração, somou 73 pontos e $31 \%$ dos entrevistados atribuíram valor +1 a ela. Possui a quarta maior porcentagem de componentes naturais $(79 \%)$, ficando atrás da paisagem 5 (100\%), paisagem 7 (83\%) e paisagem $2(82 \%)$. Analisando o elemento relevo, a paisagem 4 possui a maior porcentagem de relevo acidentado (46\%) em relação às outras paisagens, enquanto que o relevo plano apresenta $28 \%$. A montanha no plano de fundo contribui para a boa valoração da paisagem, pois as paisagens com maior 


\section{TURISMO EM ANÁLISE}

irregularidade na topografia são mais bem valoradas (TUAN, 1980; CANTERAS, 1992; PIRES, 1996 e OLIVEIRA, 2003).

A vegetação na paisagem 4 é um elemento que também contribui para sua boa valoração. Este elemento é representado por $52 \%$ de ocupação na paisagem. Segundo Boullón (2002), a vegetação atua como cobertura da topografia ou do relevo e pode representar o principal elemento visual de uma paisagem.

Os componentes antrópicos da paisagem 4 (21\%) são constituídos por edificação, infraestrutura e elementos móveis. O elemento edificação apresenta uma porcentagem alta em relação ao total de componentes antrópicos (15\%), sendo representada principalmente pela igreja. $\mathrm{O}$ elemento infra-estrutura $(2 \%)$ refere-se à calçada em direção à igreja. Na paisagem 4, ambos elementos, assim como nas paisagens 2 e 9, são de arquitetura antiga e não causam interferência negativa, pelo contrário, se harmonizam e valorizam a paisagem, conforme Pires (1996), Boullón (2002) e Silva (2004).

No caso dos elementos móveis (5\%), que possui a segunda maior porcentagem entre as paisagens, é representado pelas pessoas que participam da cena, mostra-se um dado interessante. A paisagem 4 é a única que revelou a manifestação da atividade turística através de uma concentração de pessoas (turistas). A presença da concentração de pessoas parece não interferir negativamente na percepção dos entrevistados, pois a paisagem obteve alta valoração. Isto, no entanto, contradiz o estudo de Hawthorne et al. (2007), no qual foi constatado, utilizando o mesmo Método $\mathrm{Q}$, que residentes tendem a rejeitar paisagens com presença evidente de turismo.

Quanto aos componentes turísticos, a paisagem 4 possui 27\% constituídos de atrativo natural (11\%), atrativo cultural (14\%) e infra-estrutura (2\%). O atrativo natural se apresenta como o Conjunto Marumbi ao fundo e contribui para a alta valoração da paisagem. Neste sentido Silva (2004) afirma que as paisagens turísticas são mais valorizadas quando associadas a situações geográficas naturais específicas, como montanhas, constituindo aspectos pitorescos e mais facilmente identificados na paisagem. Por sua vez, o atrativo cultural, expresso na paisagem através da Igreja de Nossa Senhora do Porto, pode ser considerado um marco na 


\section{TURISMO EM ANÁLISE}

paisagem, segundo Boullón (2002), pois se trata de um ponto de referência singular para o observador e contribui também para a alta valoração da paisagem 4 .

E, assim como as paisagens 2 e 9, a paisagem 4 apresenta variação e diferenciação de elementos, sendo considerada uma paisagem diversificada e, portanto, de acordo com Canteras (1992), Pires (1996) e Boullón (2002), uma paisagem de maior qualidade visual, o que contribui, também, para sua alta valoração.

A paisagem 7 apresentou uma valoração intermediária, com escore final de 64 pontos, situando-se na coluna central da pirâmide. $\mathrm{O}$ valor 0 (zero) foi atribuído a esta paisagem por $34 \%$ dos entrevistados.

Em relação aos componentes naturais, a paisagem 7 possui a segunda maior porcentagem (83\%), ficando atrás apenas da paisagem $5(100 \%)$. Este resultado caminha contra a tendência (já citada neste estudo) que aponta para uma forte aceitação das pessoas a respeito das paisagens que possuem predominância de componentes naturais em relação aos antrópicos (CANTERAS, 1992; PIRES, 1993 e 1996; MARENZI, 1996; HARDT, 2000; OLIVEIRA, 2003).

Isolando o elemento relevo, nota-se um equilíbrio nas percentagens de plano e acidentado, ambos com $36 \%$, porém as montanhas aparecem ao fundo sem qualquer obstrução visual. De acordo com Tuan (1980), Canteras (1992) e Pires (1996), a presença de irregularidade e singularidade na topografia deveria ser motivo para uma alta valoração. No entanto isto não acontece na paisagem 7. Tuan (1980) afirma que, apesar de ser um forte elemento estético da paisagem, as montanhas possuem um caráter desafiador ao controle humano sobre o ambiente e, elevadas acima da planície habitada, são consideradas remotas, difíceis de aproximar e perigosas.

Além disso, os componentes naturais são enriquecidos pela presença de componentes antrópicos, representados pelo cultivo agrícola (17\%), o qual é considerado uma expressão da cultura local e faz parte da personalidade do lugar, não interferindo negativamente na paisagem (MENDONÇA, 1996). 


\section{TURISMO EM ANÁLISE}

A paisagem 7 não possui complexidade e variedade de elementos na cena, portanto, é considerada uma paisagem monótona. Ao contrário das paisagens diversificadas, as paisagens monótonas, segundo Boullón (2002), são integradas por poucos elementos, sendo difícil reconhecer características que sejam capazes de diferenciá-las das demais, destacando que as paisagens monótonas podem provocar tédio em turistas comuns (que não são aventureiros).

Em relação aos componentes turísticos, a paisagem 7 apresenta o atrativo natural $(27 \%)$, representado pelo Conjunto Marumbi. Embora esta cadeia montanhosa seja um marco na paisagem de Morretes, apresentando singularidade, a presença deste atrativo, no ambiente natural, não é suficiente para uma boa valoração. A ausência de elementos, como equipamento e infra-estrutura, que podem proporcionar a aproximação e o desfrute do atrativo pelo observador pode também, neste caso, estar contribuindo para a neutralização de seus elementos paisagísticos, obtendo, portanto valoração intermediária. Neste sentido, Antrop (2000) verificou em seu estudo que as pessoas em geral preferem paisagens que possuam um uso claro, que proporcionem acessibilidade e liberdade para seus movimentos. Cavalcanti et al. (2000), por sua vez, constatou que a população valoriza o ambiente modificado, o qual de alguma forma ela possa usar. Este resultado pode estar indicando uma tendência à preferência de paisagens que possuam um grau de interferência humana, o qual não interfira visualmente na paisagem, porém, proporcione seu acesso, movimento e desfrute.

A paisagem 3 apresentou uma valoração intermediária, com escore final de 16 pontos, situando-se na coluna central da pirâmide. O valor 0 (zero) foi o mais escolhido, $38 \%$ dos entrevistados, para a valoração desta paisagem. A paisagem 3 apresenta predominância de componentes naturais $(73 \%)$ em relação aos componentes antrópicos $(27 \%)$. Assim como na paisagem 7 , a paisagem 3 não obteve maior valoração devido à predominância de componentes naturais, indo, mais uma vez, contra os estudos de qualidade da paisagem, que apontam uma tendência pela preferência de recursos naturais (ZUBE e PITT, 1981).

Na paisagem 3 o elemento água aparece em 28\% da paisagem. De acordo com Tuan (1980), Pires (1996) e Burmil et al. (1999), a água é um dos elementos visuais mais importantes e mais atrativos da paisagem. Corroborando com esta ideia, Yázigi (2002) afirmou que estudos desenvolvidos em diversos países do mundo apontaram que a preferência das pessoas é por 
paisagens que apresentaram o elemento água, com exceção de alguns povos da África, que preferiram montanhas e campos. Este autor ainda afirma que rios rodeados por vegetação são intensa fonte de atração das pessoas, entretanto aparenta não ser fundamental para sua boa valoração, já que a paisagem 3 recebeu uma valoração intermediária.

Isto pode ter acontecido devido a pouca presença do elemento vegetação (19\%), a mais baixa porcentagem do componente em relação às demais paisagens, pois, de acordo com Purcell e Lamb (1998), a vegetação é um elemento que contribui muito para a boa valoração das paisagens. E segundo Boullón (2002), a vegetação pode representar o principal elemento visual de uma paisagem. Dessa forma, paisagens com escassez de vegetação são menos preferidas àquelas que possuem o elemento em maior quantidade.

Há ainda a presença de solo exposto (1\%) na paisagem 3, em decorrência da atividade humana. A porcentagem pode ser irrelevante quantitativamente, porém visualmente representa uma intervenção negativa. Kischlat (2004), neste sentido, considerou em sua pesquisa a exposição do solo provocada pela ação do homem como uma interferência negativa à paisagem.

Quanto aos componentes antrópicos, o que chama a atenção para a paisagem 3 é a quantidade de elementos móveis (24\%), que se apresenta em maior porcentagem que o restante das paisagens analisadas. Devido à sua porcentagem se equilibrar com as percentagens dos outros elementos, pode-se dizer que os elementos móveis (barcos) contribuíram para a valoração intermediária tanto quanto os outros elementos. Lynch (1997) destaca a importância dos elementos móveis na paisagem, quando diz que a presença humana e de seus artefatos criam um vínculo com o observador. Antrop (2000) afirma, ainda, que o movimento de elementos na paisagem é apreciado, pois expressa a vida.

$\mathrm{Na}$ paisagem 3, os elementos edificação (1\%) e infra-estrutura (2\%) possuem pouca representatividade. No estudo de Kischlat (2004), as edificações (residências, muros, postes) foram consideradas como interferências humanas negativas à paisagem. Além disso, visualmente observa-se uma falta de conservação destes elementos e até mesmo dos elementos móveis, o que pode estar contribuindo para a valoração intermediária da paisagem 3. Marenzi (1996) em seu estudo constatou detração visual (valoração baixa) em paisagens 


\section{TURISMO EM ANÁLISE}

que possuíam o maior grau de naturalidade. No mesmo sentido, Hardt (2000), verificou que as paisagens com falta de tratamento dos espaços foram as menos preferidas pelo público. Concordando, Antrop (2000) afirma que a presença da aparente falta de manutenção dos elementos da paisagem costuma ser rejeitada pelas pessoas.

Quanto aos componentes turísticos, a paisagem 3 apresenta $29 \%$ de atrativos naturais, constituídos pelo Rio Nhundiaquara e pelas montanhas ao fundo. Esta porcentagem de atrativos naturais é a segunda maior, ficando atrás apenas da paisagem 2, a qual obteve a maior valoração. No entanto, assim como na paisagem 7, a paisagem 3 não possui o elemento equipamento e infra-estrutura importantes para provocar o sentido de liberdade de movimento, o uso e o desfrute da paisagem, valorizados pelo público (ANTROP, 2000; CAVALCANTI et al., 2000), o que pode estar também contribuindo para sua valoração intermediária.

A paisagem 8 foi considerada uma paisagem intermediária, localizando-se na coluna central da pirâmide. Recebeu -52 pontos e $44 \%$ dos entrevistados atribuíram valor 0 (zero) à paisagem.

Em relação aos componentes naturais, a paisagem 8 possui a terceira menor porcentagem (67\%), ficando atrás da paisagem $1(31 \%)$ e da paisagem 9 (64\%). Assim como observado nas análises das demais paisagens, a maior porcentagem de componentes naturais não parece ser relevante para a preferência do público, contrariando a tendência dos estudos de Canteras (1992), Pires (1996), Marenzi (1996), Hardt (2000) e Oliveira (2003).

Entre os componentes naturais, a paisagem 8 apresenta porcentagens equilibradas entre relevo plano (24\%) e relevo acidentado (28\%). Uma cadeia montanhosa se revela ao fundo obstruída visualmente por vegetação e infra-estrutura. A presença de relevo na paisagem, conforme afirmado por Tuan (1980), Canteras (1992), Pires (1993), Boullón (2002) e Oliveira (2003) tem a capacidade de atrair as pessoas e contribuir para a qualidade visual da paisagem. A presença do relevo acidentado na paisagem 8 pode ter influenciado positivamente a preferência dos entrevistados.

O que chama a atenção para a paisagem 8 é o fato de possuir a maior porcentagem do elemento céu (48\%) entre todas as paisagens e entre seus próprios componentes. O elemento 


\section{TURISMO EM ANÁLISE}

céu, entre as paisagens selecionadas para a pesquisa, apresentou condições climáticas semelhantes e parece não ter influenciado de maneira negativa ou positiva a preferência dos entrevistados, comportando-se, portanto, de maneira neutra. No trabalho de Kischlat (2004), o céu teve o mesmo comportamento. Em seu estudo, tendo em vista que a participação do céu variou bastante de uma foto para outra, ele foi considerado um elemento que não influenciou nos cálculos da integridade paisagística. Assim, o elemento céu parece não apresentar, neste caso, importância quantitativa para as análises das paisagens.

Com relação aos componentes antrópicos (33\%), os elementos edificação (13\%) e infraestrutura (20\%) apresentam interferência na paisagem. Ao contrário das paisagens 2, 9 e 4 (que possuem significativas percentagens destes elementos) na paisagem 8, a edificação e infra-estrutura se apresentam com arquitetura moderna, fugindo ao padrão das paisagens anteriores.

A arquitetura de estilo antigo, inserida na paisagem natural, de acordo com Bley (1990) e Silva (2004), pode ser considerada um elemento que confere singularidade e tipicidade à paisagem e, portanto, acrescenta valor. No entanto, a paisagem 8 apresenta edificações modernas, sem rigor estético, as quais contrastam com os elementos naturais do entorno, criando uma desarmonia visual. E, a infra-estrutura se apresenta, predominantemente, como estrada asfaltada de traçado retilíneo, com um sentido rígido e inflexível. Conforme Kischlat (2004), as pessoas tendem preferir estradas sinuosas, que passam a idéia de mistério e movimento à paisagem. Nos estudos de Oliveira (2003) e Kischlat (2004) as paisagens que apresentaram edificações e infra-estruturas marcantes tiveram as piores classificações de acordo com a preferência dos entrevistados. Assim como nestes estudos, as edificações e infra-estrutura podem estar contribuindo para a valoração intermediária da paisagem.

Abordando os componentes turísticos da paisagem 8 (39\%), o atrativo natural (6\%) é representado pela montanha e possui um apelo visual positivo (PIRES, 1996). Os equipamentos $(12 \%)$, representado pelos restaurantes e lanchonetes e a infra-estrutura $(20 \%)$, pela estrada, como se afirmou anteriormente constituem um aspecto negativo na paisagem. Boullón (2002), quando se refere aos equipamentos, diz que as construções, levantadas inicialmente de maneira improvisada para atender a demanda, não possuem critério 
paisagístico algum e podem contribuir para a degradação da paisagem, diminuindo sua atratividade. Hardt (2000) também afirmou que as paisagens com falta de tratamento estético foram as menos valoradas em sua pesquisa. E Silva (2004) diz que a necessidade de atender à demanda turística da paisagem pode comprometer seus atributos paisagísticos. A falta de preocupação estética das edificações e a rigidez da infra-estrutura na paisagem 8 podem estar indicando um fator de rejeição à preferência dos entrevistados, contribuindo para a valoração intermediária que recebeu.

A paisagem 5, considerada a terceira com menor valoração, apresenta $33 \%$ das escolhas dos entrevistados atribuídos ao valor -1 , resultando em -84 pontos em seu escore final. Esta paisagem é constituída de $100 \%$ de elementos naturais (a cerca ou divisória do terreno não obteve porcentagem significativa). Contrariando mais uma vez, estudos de qualidade visual paisagística (CANTERAS, 1992; PIRES, 1993 e 1996; MARENZI, 1996; HARDT, 2000; FAIRWEATHER, 2000; OLIVEIRA, 2003), a paisagem 5 possui a maior porcentagem de componentes naturais e vegetação (69\%), porém obteve menor valoração.

Pode-se justificar esta contradição, analisando os resultados de Kischlat (2004), os quais demonstraram que as pastagens foram consideradas como interferência humana negativa à paisagem. Já Ulrich (1986) afirmou que a baixa preferência por paisagens naturais geralmente está associada a fatores de baixa complexidade (que não prendem a atenção do observador), a desordem e ausência de ponto focal. Aplicando a afirmação de Ulrich (1986) à paisagem 5, pode-se notar que a vegetação arbórea apresenta-se espalhada desordenadamente na paisagem, formando vazios ocupados por vegetação rasteira. Apresenta ainda ausência de elementos nítidos na paisagem que conformem um ponto de referência, confirmando a idéia do autor e contribuindo para justificar a baixa valoração da paisagem 5 .

A fauna aparece apenas na paisagem 5 , com menos de $1 \%$, entretanto visualmente podem ter influenciado negativamente na percepção dos entrevistados devido a seu tamanho reduzido, pois, de acordo com Antrop (2000), os elementos que aparecem na paisagem e que fogem à escala humana (muito pequenos ou muito grandes) não são apreciados pelo observador.

Além disso, a paisagem 5 apresenta pouca profundidade e poucos componentes, assim, pode ser considerada uma paisagem fechada e monótona. Embora se observe melhor os detalhes 


\section{TURISMO EM ANÁLISE}

numa paisagem fechada do que numa paisagem aberta, Boullón (2002) afirma que neste caso pode-se ter uma visão parcial da paisagem, limitado a visão e a apreciação. As paisagens monótonas tendem a ser menos preferidas, pois não apresentam uma combinação variada de elementos e permitem, na maioria dos casos, uma diferenciação das demais paisagens, e a singularidade fica comprometida (CANTERAS, 1992; PIRES, 1996; BOULLÓN, 2002). Isto pode estar contribuindo para a baixa valoração da paisagem 5 .

Outro aspecto que pode estar contribuindo para a baixa valoração da paisagem 5 é a ausência de componentes turísticos na paisagem. A falta de atrativo (motivação para as pessoas conhecerem a paisagem), a falta de a infra-estrutura (ajuda à demanda ao acesso e desfrute da paisagem) e a falta de equipamento (atendimento das necessidades da demanda) pode inibir a visitação e diminuir a atratividade da paisagem para as pessoas comuns.

A paisagem 6, considerada a segunda paisagem menos valorada, recebeu -149 pontos, sendo que a maior porcentagem de entrevistados, $46 \%$, atribuiu o valor -1 à paisagem 6 . Com a análise dos componentes paisagísticos, observa-se que a paisagem 6 possui predominância dos elementos naturais (72\%), e contrariando novamente os estudos que constaram maior qualidade visual às paisagens com mais recursos naturais em relação aos antrópicos (CANTERAS, 1992; PIRES, 1996; MARENZI, 1996; HARDT, 2000; OLIVEIRA, 2003) a paisagem 6 recebeu menos valoração.

Analisando o elemento relevo, na paisagem 6 há a predominância do relevo plano $(40 \%)$ em relação ao acidentado (17\%). Tuan (1980), Pires (1996) e Oliveira (2003) verificaram em seus estudos que as paisagens que possuíam relevo acentuado possuíam maior qualidade visual. Isto pode estar indicando que a predominância de relevo plano contribuiu para a baixa valoração.

A vegetação da paisagem 6 aparece com $28 \%$, uma porcentagem intermediária comparada às outras paisagens. É representada por árvores ao fundo e grama aparada, proporcionando na visão de Silva (2004), um aspecto de conforto ao visitante e acesso ao ambiente natural.

Quanto aos componentes antrópicos, assim como na paisagem 8, as edificações e infraestruturas possuem arquitetura de estilo moderno, que foge do padrão típico da paisagem de Morretes (Bley, 1990) e faz com a que esta perca sua identidade, apresentando interferências 


\section{TURISMO EM ANÁLISE}

visuais negativas na paisagem. Este resultado corrobora com os estudos de Oliveira (2003) e Kischlat (2004), nos quais as paisagens menos valoradas foram as que apresentaram edificações e infra-estruturas em desarmonia com as paisagens avaliadas.

Em relação aos componentes turísticos, a paisagem 6 apresenta $15 \%$ de equipamento, representada pelo centro de visitantes e $12 \%$ de infra-estrutura, representada pelos bancos, lixeiras, sinalização, poste e ponte. Ao contrário da paisagem 8 , onde os equipamentos são propriedade privada e não houve, a princípio, preocupação estética na sua construção, a paisagem 6 apresenta uma estrutura pública criada para atender a demanda turística já existente no local. Pode-se afirmar que houve um processo de planejamento para sua instalação, entretanto, faltou um critério que determinasse a adequação da construção com a identidade do lugar coerente com a singularidade e tipicidade da paisagem, apontado por Boullón (2002) como um aspecto de muita importância para a valorização visual da paisagem. Bley (1990) também afirma que a paisagem de Morretes é percebida como um conjunto, um todo coerente.

Além disso, o centro de visitantes encontra-se desativado (e, portanto, sem utilização oficial), pois se localiza em área de preservação permanente, na beira do Rio Nhundiaquara. E para quem não conhece a paisagem, sua utilidade não é facilmente percebida. Neste sentido, Antrop (2000) diz que as paisagens mais preferidas são aquelas que possuem seu potencial de uso bem claro, e, no contrário, produzem um sentimento de inutilização.

A paisagem 1, considerada a paisagem menos valorada, recebeu -176 pontos, correspondendo a $36 \%$ dos entrevistados que atribuíram valor -2 à paisagem. Com relação aos componentes paisagísticos, observa-se que na paisagem 1 que nos elementos naturais há uma predominância do relevo plano $(90 \%)$ e nos elementos antrópicos há predominância das edificações e infra-estrutura, com (69\%).

Isolando o componente relevo, as paisagens que apresentam maior porcentagem de relevo plano são as paisagens 1 e a paisagem 9. Embora a paisagem 1 tenha ficado entre as piores e a paisagem 9 entre as melhores. Isso pode estar indicando que na paisagem 9 tenha outros elementos naturais no contexto dos componentes paisagísticos com maior valoração neutralizando a alta porcentagem do elemento relevo plano e fazendo com que este não seja o 


\section{TURISMO EM ANÁLISE}

maior responsável pela colocação desta paisagem nas mais bem valoradas. Caso esta preferência, de maior valoração nas paisagens de relevo plano, venha se confirmar pode não estar exprimindo as comprovações de Oliveira (2003), pois geralmente as paisagens que apresentam relevo acidentado são as mais bem valoradas do que as de relevo plano (CANTERAS, 1992).

O que chama mais a atenção na paisagem 1 é que ela é uma das paisagens com a menor porcentagem de vegetação e a única com porcentagem maior de componentes antrópicos que componentes naturais. De acordo com Zube e Pitt (1981), os estudos de percepção demonstram repetidamente que os recursos naturais da paisagem são considerados mais belos que aqueles marcados pela intervenção antrópica. Acredita-se que este seja um dos principais motivos para a rejeição à paisagem 1, pois a proporção entre os componentes é muito diferente.

Além disso, na paisagem 1 o elemento edificação apresenta falta de conservação da fachada. Esta "falta de tratamento dos espaços", chamada por Hardt (2000), ou "detração visual", chamada por Marenzi (1996) é um fator que diminuiu a valoração das paisagens em suas respectivas pesquisas sobre a qualidade da paisagem, mesmo naquelas em que há maior grau de naturalidade.

De acordo com Boullón (2002), “do mesmo modo que uma árvore magnífica perde seu valor estético se estiver cercada por uma lixeira, um edifício, uma igreja, ou um monumento diminuem sua beleza se o espaço que os circunda não se harmoniza com sua arquitetura ou escala".

Quanto aos componentes turísticos a paisagem 1 apresenta $38 \%$ de atrativo cultural e $31 \%$ de infra-estrutura. Esta paisagem apresenta a maior porcentagem de componentes turísticos, concentrados apenas nos dois componentes acima, não tendo maior diversidade de componentes para o turismo. Boullón (2002) afirmou que uma das formas de analisar a paisagem é através da diversidade de componentes que nela se encontra. E também, Gonzalez Bernáldez (1981) afirmou que as paisagens características de uma região, por tanto as que possuem identidade, são determinadas pela associação característica de alguns componentes paisagísticos. Voltando a Boullón (2002), as paisagens homogêneas (caso da paisagem 1), são 
as que estão integradas por muito poucos elementos e são as que apresentam dificuldade em diferenciá-las ou reconhecê-las e que, por sua monotonia, entediam as pessoas mais facilmente.

Como resultado das preferências separadas por categorias, observa-se que a opinião dos residentes diferencia-se da geral nas paisagens com valoração intermediária e baixa (tabela 1). A opinião dos turistas se diferencia da geral em relação às paisagens de valoração alta $\mathrm{e}$ intermediária. E a opinião mais distinta é a dos profissionais, que difere da preferência geral na maioria das paisagens.

Tabela 1 - Preferência das paisagens por categoria

\begin{tabular}{|c|c|c|c|c|c|}
\hline \multicolumn{2}{|c|}{ Valoração } & $\begin{array}{l}\text { Preferência } \\
\text { Geral }\end{array}$ & $\begin{array}{l}\text { Preferência } \\
\text { Residentes }\end{array}$ & $\begin{array}{l}\text { Preferência } \\
\text { Turistas }\end{array}$ & $\begin{array}{c}\text { Preferência } \\
\text { Profissionais }\end{array}$ \\
\hline \multirow{3}{*}{ Valoração Alta } & +2 & P 2 & P 2 & P 2 & P 7 \\
\hline & \multirow{2}{*}{+1} & P 9 & P 9 & P 7 & P 3 \\
\hline & & P 4 & P 4 & $\mathrm{P} 4$ & P 4 \\
\hline \multirow{3}{*}{$\begin{array}{c}\text { Valoração } \\
\text { Intermediária }\end{array}$} & \multirow{3}{*}{$\mathbf{0}$} & P 7 & P 7 & P 9 & P 2 \\
\hline & & P 3 & P 6 & P 3 & P 9 \\
\hline & & $\mathrm{P} 8$ & P 8 & P 8 & $\mathrm{P} 1$ \\
\hline \multirow{3}{*}{$\begin{array}{c}\text { Valoração } \\
\text { Baixa }\end{array}$} & \multirow{2}{*}{-1} & P 5 & P 3 & P 5 & P 8 \\
\hline & & P 6 & P 5 & P 6 & P 5 \\
\hline & -2 & P 1 & P 1 & P 1 & P 6 \\
\hline
\end{tabular}

Fonte: as autoras, 2009.

Quando se relaciona a preferência dos residentes com a preferência geral, nota-se um consenso a respeito das colocações da maioria das paisagens, destacando as paisagens de maior valoração (Paisagem 2) e menor valoração (Paisagem 1). Entretanto as valorações das paisagens 6 e 3 divergiram em relação à preferência geral (tabela 1).

A valoração da paisagem 6 aumentou de -1 para 0 (zero). Sabendo que esta paisagem possui uma marcante presença de edificação em estilo moderno, e recebeu menor valoração dos outros dois grupos, percebe-se que este elemento não interfere negativamente na preferência dos residentes. Isso pode estar corroborando com o resultado do estudo de Zube e Pitt (1981), no qual os residentes não consideravam que as edificações depreciavam a paisagem local. 


\section{TURISMO EM ANÁLISE}

Além disso, por conhecer a paisagem 6, os residentes podem ter atribuído maior valor à paisagem por conseguirem identificar a função da edificação (centro de visitantes), embora esteja desativado. Neste sentido, Antrop (2000) cita que a paisagem é mais apreciada quando seu potencial de uso é claro, conhecendo a razão para a edificação existir na paisagem.

Quanto à paisagem 3, sua valoração migrou do valor 0 (zero) para o valor -1 . Pode-se utilizar a afirmação de Bley (1990), que destaca que a atribuição de valor dos residentes à paisagem está intimamente ligada com a solução de problemas de atendimento às necessidades básicas. A paisagem 3 indica, pela quantidade de barcos (elementos móveis), que é utilizada pela população em seu cotidiano. Aproximando a afirmação de Bley para a paisagem 3, é possível afirmar que esta não satisfaz as necessidades da população por falta de infra-estrutura que os atenda. Talvez por isso, a paisagem 3 não agradou aos residentes.

Marion e Machado (1999) afirmam que só quem vivencia a paisagem por meio de um contato direto e contínuo pode alcançar sua melhor compreensão. As relações dos moradores com as paisagens são baseadas na familiaridade com seus elementos e permitem seu melhor entendimento e aproveitamento. Bley (1990) diz que as paisagens são mais valorizadas para os residentes quando estas atendem suas necessidades. Assim, pode-se afirmar que existe uma expectativa dos residentes em relação à paisagem no sentido da sua funcionalidade. E por ter seu modo de vida afetado por decisões a respeito da paisagem, conhecer a opinião dos residentes torna-se importante para o planejamento.

A preferência dos turistas em relação à preferência geral das paisagens difere na valoração alta e intermediária (tabela 1). A paisagem 7 recebeu valor 0 (zero) na preferência geral, enquanto que na preferência dos turistas ela aumentou para valor 1. No caso da paisagem 9 , esta recebeu valor 1 na preferência geral e na dos turistas, recebeu valor 0 . Levando em consideração a afirmação de Tuan (1980) a qual diz que a percepção do visitante "frequentemente se reduz a usar seus olhos para compor quadros", pode-se dizer que os turistas preferiram a paisagem 7 em relação a 9 de acordo com seu julgamento estético. Além disso, a diferença da percepção entre os turistas e residentes a respeito da paisagem 7 reside em parte na afirmação de Bley (1990) de que os moradores, em decorrência da familiaridade com o contorno da serrania, a ignoram, pois quando as montanhas se tornam acessíveis, 


\section{TURISMO EM ANÁLISE}

perdem sua aparência proibida e a emoção em relação a elas diminui. Ao contrário do que acontece com os turistas, que se impressionam com as montanhas.

Corroborando com a ideia de Tuan (1980), Mendonça (1996) afirma que a avaliação do meio ambiente pelo visitante é puramente estética. O estranho ao meio normalmente julga pela aparência, por um critério formal de beleza. Neste sentido, interpreta-se que a expectativa dos turistas em relação às paisagens seja estética, de apreciação do belo, do que é harmonioso. Por ter sua receita originada da atividade turística, Morretes necessita de planejamento para satisfazer as expectativas dos turistas. Dessa forma, conhecer a preferência dos turistas em relação à paisagem torna-se fundamental para a continuidade do turismo no município.

Para a categoria dos profissionais, as paisagens 2, 9 e 8 tiveram seus valores diminuídos em detrimento do aumento dos valores das paisagens 7,3 e 1 em relação à preferência geral. Sabe-se que as paisagens 2 e 9 possuem mais componentes antrópicos que as paisagens 7 e 3 , que possuem maior nível de naturalidade.

O que chama atenção para a preferência dos profissionais é a contradição de opinião com relação a paisagem 1. Esta paisagem foi rejeitada pelas outras categorias por apresentar maior quantidade de componentes antrópicos com falta de tratamento. Entretanto, os profissionais conseguem enxergar a importância do atrativo cultural na paisagem (38\%), atribuindo mais valor a ela do que os residentes e turistas. Isto pode estar indicando que se a paisagem receber tratamento estético, através do restauro, seu valor poderá aumentar em relação à preferência das outras categorias, mesmo apresentando predominância de componentes antrópicos (69\%).

De acordo com Kaplan e Herbert (1987), os profissionais possuem uma preocupação com a conservação das paisagens. Paisagens que possuem o maior nível de naturalidade tendem a ser preferidas pela categoria. Dessa forma, o arranjo das paisagens dos profissionais indicou existir uma preferência por paisagens que apresentassem menos interferência humana negativa.

De acordo com Canteras (1992), a percepção das paisagens está relacionada com os fatores inerentes ao próprio indivíduo (capacidade imaginativa e cognitiva), fatores educativos e culturais (padrões e atitudes culturais influenciados pela forma de aprendizagem) e fatores emotivos (familiaridade, conhecimento e afeição). Neste sentido, as preferências por 
categorias dos entrevistados - residentes, turistas e profissionais - apresentaram características distintas entre si, principalmente a respeito das relações (afeição e expectativa) que estabelecem com as paisagens. Tuan (1980) afirma que o visitante e o nativo focalizam aspectos bem diferentes da paisagem. Enquanto o residente está imerso na paisagem, o turista está apenas de passagem e, por sua vez, os profissionais possuem um ponto de vista próprio, direcionado por suas linhas de aprendizagem e trabalho.

É importante destacar que os profissionais foram entrevistados pessoalmente em seus gabinetes ou por e-mail, ao contrário dos residentes e turistas que foram entrevistados em Morretes. Isto pode ter influenciado na preferência das paisagens, pois a categoria de profissionais não estavam vivenciando a paisagem no momento da entrevista, embora já conhecessem Morretes.

Os resultados obtidos neste estudo indicam a importância da análise da preferência das paisagens como subsídio ao planejamento da paisagem para o turismo, revelando que cada categoria possui um tipo de relacionamento com as paisagens, e, portanto, preferências, expectativas e anseios característicos.

\section{Conclusões}

O Método Q aplicado mostrou-se eficiente, pois os entrevistados foram induzidos a comparar as fotografias selecionadas (paisagens) umas com as outras, atribuindo valor a elas. Dessa forma, a valoração pelo Método $\mathrm{Q}$ conseguiu extrair as reais opiniões, impressões e expectativas dos entrevistados em relação à paisagem de Morretes.

Quanto aos componentes paisagísticos e turísticos na análise da preferência das paisagens, os resultados mostraram principalmente que a predominância de elementos antrópicos na paisagem foi rejeitada pelos respondentes, embora a predominância de componentes naturais por si só não foram suficientes para garantir uma boa valoração da paisagem. Isto demonstra que o fator diversidade mostrou-se determinante para a alta valoração das paisagens, corroborando com a literatura existente.

Quando se separaram os resultados da preferência das paisagens de acordo com as categorias 


\section{TURISMO EM ANÁLISE}

de entrevistados, os resultados demonstraram que os residentes, turistas e profissionais possuem preferências, visões, opiniões e expectativas diferentes em relação às paisagens. Os residentes preferiram paisagens com um sentido de funcionalidade e que atendem às suas necessidades; os turistas ordenaram as paisagens de acordo com um critério estético, preferindo paisagens belas e harmônicas; e os profissionais mostraram uma preocupação com a conservação das paisagens, dando preferência a presença do fator naturalidade. Este resultado demonstra a importância de um processo participativo de planejamento e gestão das paisagens para o turismo, o qual somaria as opiniões e expectativas dos usuários (residentes e turistas) com a visão técnica dos profissionais.

\section{Referências}

ANTROP, M. Background Concepts for Integrated Landscape Analysis. Agriculture, Ecossystems \& Environment, 2000, no. 77, p. 17-28.

BIGRAS, M.; DESSEN, M. A. O Método Q na Avaliação Psicológica: Utilizando a Família como Ilustração. Aval. psicol., nov. 2002, vol.1, no.2, p.119-131.

BLEY, L. Morretes: Estudo de Paisagem Valorizada. Rio Claro: UNESP, 1990. (Tese de Doutorado). BOULLÓN, R. C. (trad. Josely Vianna Baptista). Planejamento do Espaço Turístico. Bauru, SP: EDUSC, 2002.

BURMIL, S.; DANIEL, T. C.; HETHERINGTON, J. D. Human Values and Perceptions of Water in Arid Landscapes. Landscape and Urban Planning, 1999, 44: 99-109.

CANTERAS, J. C. Introducción al Paisaje. Curitiba: UFPR, Universidad de Cantabria, 1992.

CAVALCANTI, D. C.; CARDOSO-LEITE, E.; COVRE, T. B.; DEGASPERI, T. H.; FERNANDES, M. R.;

FAIRWEATHER, J. R.; SWAFFIELD, S. R.; SIMMONS, D. G. Understanding Visitor's Experiences in Kaikoura Using Photographs of Landscapes and $Q$ method. Canterbury: Lincoln University, Tourism Research and Education Centre, Report n ${ }^{\circ}$, 1998. (Monograph). Disponível em: $<$ http://researcharchive.lincoln.ac.nz/dspace/handle/10182/104>, acesso em: 15/05/2008.

FAIRWEATHER, J. R.; SWAFFIELD, S. R.; SIMMONS, D. G. Visitor's and Local's Experiences of Rotorua Using Photographs of Landscapes and Q method. Canterbury: Lincoln University, Tourism Research and Education Centre, Report $\mathrm{n}^{\mathrm{o}}$ 13, 2000. (Monograph). Disponível em: $<$ http://researcharchive.lincoln.ac.nz/dspace/handle/10182/117>, acesso em: 15/05/2008.

GOELDNER, C. R.; RICHIE, J. R. B.; MCINTOSH, R. W. (trad. Roberto Cataldo Costa) Turismo. Princípios, Práticas e Filosofias. 8ªd. Porto Alegre: Bookman, 2002.

GONZALEZ-BERNALDEZ, F. Ecología y Paisaje. Madrid: H. Blume Ediciones, 1981.

GRISE, M.M. Mapa de localização da área de estudo. 2009. 


\section{TURISMO EM ANÁLISE}

HAWTHORNE, T.; KRYGIER, J.; KWAN, M.; Mapping Ambivalence: Exploring the Geografies of Community Change and Rails-to-rails Development Using Photo-based Q Method and PPGIS. Geoforum, Volume 39, 2008, pages 1058-1078.

KAPLAN, R.; HERBERT, E. J. Cultural and Sub-Cultural Comparisons in Preferences for Natural Settings. Landscape and Urban Planning, 1987, 14: 281-293.

KISCHLAT, E. Metodologia para Avaliação da Preferência Visual de Recursos Naturais da Paisagem para Fins Turísticos. Estudo de Caso nos Municipios de Benedito Novo e Dr. Pedrinho SC. Curitiba: UFPR, 2004. (Dissertação de Mestrado).

LYNCH, K. A Imagem da Cidade. São Paulo: Martins Fontes, 1997.

MARENZI, R. C. Estudo da Valoração da Paisagem e Preferências Paisagísticas no Município da Penha - SC. Curitiba: UFPR, 1996. (Dissertação de Mestrado).

OLIVEIRA, D. A. de. Ecologia e Valoração da Paisagem do Entorno da Cidade de Paranaguá. Curitiba: UFPR, 2003 (Dissertação de Mestrado).

ORGANIZAÇÃO MUNDIAL DO TURISMO. Introdução ao Turismo. São Paulo: Roca, 2001.

PARANÁ CIDADE/SECRETARIA DE ESTADO DO DESENVOLVIMENTO URBANO (SEDU). Plano Diretor Municipal de Morretes. Curitiba, 2008.

PARANÁ TURISMO/SECRETARIA DE ESTADO DO TURISMO (SETU). Litoral: Estudo da Demanda Turística 2006. Curitiba, 2007.

PIRES. P. S. Avaliação da Qualidade Visual da Paisagem na Região Carbonifera de Criciúma-SC. Curitiba: UFPR, 1993. (Dissertação de Mestrado).

PURCELL, A. T.; LAMB, R. J. Preferences and Naturalness: an Ecological Aproach. Landscape and Urban Planning, 1998, 42: 57-66.

SILVA, M. da G. L. da. Cidades Turísticas: Identidades e Cenários de Lazer. São Paulo: Aleph, 2004. (Série Turismo).

TUAN, Y. F. (trad. Lívia de Oliveira). Topofilia. Um Estudo da Percepção, Atitudes e Valores do Meio Ambiente. São Paulo: Difel, 1980.

ULRICH, R. S. Human Responses to Vegetation and Landscapes. Landscape and Urban Planning, 1986, 13: 29- 44.

YÁZIGI, E. (org.). Turismo e Paisagem. São Paulo: Contexto, 2002.

A Alma do Lugar. Turismo, Planejamento e Cotidiano em Litorais e Montanhas. $2^{\mathrm{a}}$ Ed. São Paulo: Contexto, 2001. (Coleção Turismo Contexto).

ZUBE, E. H.; PITT, D. G. Cross-cultural Perceptions of Scenic and Heritage Landscapes. Landscape Planning, 8: 69-87. New York, Elsevier Scientific Publishing Company, 1981.

ZUBE, E. H.; SELL, J. L.; TAYLOR, J. G. Landscape Perception: Research, Application and Theory. Landscape Planning, 9:1-33. New York, Elsevier Scientific Publishing Company, 1982.

\section{Recebido em: 04/12/2010}

Aprovado em: 15/03/2011 (1 ${ }^{\mathrm{a}}$ versão) 08/08/2011 (2 $2^{\mathrm{a}}$ versão) 